\title{
Predictors of musculoskeletal manifestations in paediatric patients presenting with sickle cell disease at a tertiary teaching hospital in Lusaka, Zambia
}

\section{R. M. Musowoya, P. Kaonga, A. Bwanga, C. Chunda-Lyoka, C. Lavy, J. Munthali}

Aims

Sickle cell disease (SCD) is an autosomal recessive inherited condition that presents with a number of clinical manifestations that include musculoskeletal manifestations (MM). MM may present differently in different individuals and settings and the predictors are not well known. Herein, we aimed at determining the predictors of MM in patients with SCD at the University Teaching Hospital, Lusaka, Zambia.

\section{Methods}

An unmatched case-control study was conducted between January and May 2019 in children below the age of 16 years. In all, 57 cases and 114 controls were obtained by systematic sampling method. A structured questionnaire was used to collect data. The different MM were identified, staged, and classified according to the Standard Orthopaedic Classification Systems using radiological and laboratory investigations. The data was entered in Epidata version 3.1 and exported to STATA 15 for analysis. Multiple logistic regression was used to determine predictors and predictive margins were used to determine the probability of MM.

\section{Results}

The cases were older median age 9.5 (interquartile range (IQR) 7 to 12) years compared to controls 7 (IQR 4 to 11) years; $p=0.003$. After multivariate logistic regression, increase in age (adjusted odds ratio $(A O R)=1.2,95 \%$ confidence interval $(\mathrm{Cl}) 1.04$ to $1.45 ; p=0.043$ ), increase in the frequency of vaso-occlusive crisis (VOC) (AOR $=1.3,95 \% \mathrm{Cl} 1.09$ to $1.52 ; \mathrm{p}$ $=0.009)$ and increase in percentage of haemoglobin $\mathrm{S}(\mathrm{HbS})(\mathrm{AOR}=1.18,95 \% \mathrm{Cl} 1.09$ to $1.29 ; p<0.001$ ) were significant predictors of MM. Predictive margins showed that for a 16-year-old the average probability of having MM would be 51 percentage points higher than that of a two-year-old.

\section{Conclusion}

Increase in age, frequency of $\mathrm{VOC}$, and an increase in the percentage of $\mathrm{HbS}$ were significant predictors of MM. These predictors maybe useful to clinicians in determining children who are at risk.

Cite this article: Bone Joint Open 2020;1-6:175-181.

Keywords: Sickle Cell Disease, Sickle Cell Anaemia, Musculoskeletal Manifestations, Vaso-Occlusive Crisis, Haemoglobin S (HbS), Haemoglobin SS (HbSS), Zambia

\section{Introduction}

Sickle cell disease (SCD) is an autosomal recessive inherited condition characterized by the inheritance of two abnormal genes coding for haemoglobin, resulting in the formation of abnormal haemoglobin $S$
$(\mathrm{HbS}),{ }^{1}$ where the soluble amino acid valine is substituted by glutamic acid at position six in the $\beta$ globin chain. This can be either homozygous when both $\beta$ globin genes are abnormal and the resultant haemoglobin is insoluble causing sickle cell anaemia (SCA), 
or heterozygous ${ }^{2,3}$ when only one chain is involved and the patients are generally asymptomatic. Heterozygous cases are also known as carriers. Annually, more than 300,000 infants are born with SCD, and the number is expected to rise to 400,000 by $2050 .^{2,4,5}$ The highest prevalence of SCD is found in resource-poor settings, especially in sub-Saharan Africa which has about $75 \%$ of the world's cases and has challenges to reduce morbidity and mortality. ${ }^{6}$

Acute vasoocclusive crisis is the hallmark of SCD and is the most common acute presentation. ${ }^{7}$ Musculoskeletal manifestations (MM) are the commonest clinical presentations of both acute and chronic cases. ${ }^{7}$ The commonest MM that present in SCD are avascular necrosis (AVN) of the hip, osteomyelitis, septic arthritis, leg ulcers, growth retardation and skeletal immaturity, dactylitis, osteoporosis, and vertebral collapse and arthritis. ${ }^{8}$

Studies have shown a high prevalence of $\mathrm{MM}$ of SCD in children especially in West Africa: for example, Chinawa et $\mathrm{al}^{9}$ in Nigeria found a prevalence of $32.1 \%$ of MM. However, few studies that we have identified have established the predictors of these MM. One helpful study in Nigeria by Eyichukwu et al ${ }^{10}$ reported that before the age of ten years, approximately $90 \%$ of sickle cell anaemia patients developed osteomyelitis of one or more bones. They noted that the factors that predispose these patients to musculoskeletal infections include hyposplenism, impaired complement activity, and the presence of infarcted and necrotic bone. In Uganda, a study revealed that increase in age, highly demanding physical activity status and an increased frequency of painful crises were associated factors of MM in SCD patients. ${ }^{11}$

Zambia has a carrier rate of about $17.5 \%$ for SCD, ${ }^{12}$ and the University Teaching Hospital currently follows up over 1050 children with SCD of whom the majority present very late with advanced $\mathrm{MM} .^{13}$ However, no studies have been done on the potential predictors of MM of SCD patients in our setting. Therefore, this study was aimed at assessing the potential predictors of MM in paediatric patients presenting with SCD at the University Teaching Hospital, Lusaka, Zambia.

\section{Methods}

Study design and setting. An unmatched case-control study was conducted prospectively to assess predictors of MM in SCD and cases were children below the age of 16 years with MM confirmed by radiological and laboratory investigations who presented at the University Teaching Hospital, while controls were children with SCD in the same age group who presented at the same facility but without MM. Recruitment of patients was done from paediatric admission ward, sickle cell clinic, and surgical admission ward, and the study was conducted from January to May 2019.
Inclusion and exclusion criteria. All SCD patients were 16 years or below. We excluded SCD patients who had presented with other co-morbidities that have MM such as rheumatoid arthritis.

Sample size. The sample size determined for the study was calculated using the formula when the interest is to test a hypothesis comparing some exposure of two groups. Considering vaso-occlusive crisis (VOC) as the most important predictor for MM, Proportion 1 (P1) which is the risk of musculoskeletal manifestation among those with VOC was determined based on the latest data from audit records from the study site, which showed that $60 \%$ of SCD patients had VOC. Similarly Proportion 2 (P2) was determined based on the paediatric prevalence of VOC SCD patients without MM on the single point estimate, which was $8.5 \%$ with $90 \%$ Power.

$N=\left(Z_{a}+Z_{b}\right)^{2} *\left(P_{1}\left(1 P_{1}\right)+P_{2}\left(1 P_{2}\right)\right) /\left(P_{1}-P_{2}\right)^{2}$ where:

$\mathrm{N}=$ Sample size

$Z_{a}=Z$ static (usually 1.96 ) when using $95 \%$ confidence interval

$Z_{b}=20 \%$ beta error; $80 \%$ power desired (one-tailed test); $Z_{b}=0.84$

$\mathrm{P}_{1}=$ Patients with MM (60\% VOC)

$\mathrm{P}_{2}=$ Patient without MM (35\% VOC) $\mathrm{d}=$ accepted accuracy range ( $\pm 10 \%)$

The sample size calculated was 58 cases (patients with $\mathrm{MM}$ ) and 114 controls (SCD patients without MM). A ratio of 1:2 between SCD patients with $M M$ and those without was applied. All patients meeting the inclusion criteria were systematically randomly sampled.

Study procedure. The patients that were enrolled in the study were assessed according to routine clinical practice. These patients were assessed for the MM. A standard form/tool was used during the assessment. The different MM were identified, staged, and classified according to the Standard Orthopaedic Classification Systems. Radiography (digital x-rays) and laboratory investigations were used in staging and classifying of these MM. In the case of infection such as osteomyelitis and septic arthritis, deep tissue cultures were collected during operative procedures as planned by the managing orthopaedic units. These samples were taken to the laboratory for microscopy, culture, and sensitivity. Blood samples were also be taken for laboratory investigations. We ensured that the patients remained comfortable during the procedures and that minimal pain was caused by the needle during blood collection. Staging the severity of chronic osteomyelitis was done using the Beit Cure classification ${ }^{14}$ (Table I). The Ficats classification was used in the staging of AVN of the femoral head. ${ }^{15}$

Data analysis. The data was collected using a structured questionnaire and data was entered into Epi data version 3.1 (Epidata Corp, Odense, Denmark) and exported into Stata 15 (StataCorp, College Station, Texas, USA) for analysis. Descriptive statistics were used to summarize 
Table I. The Beit Cure classification staging of severity of the chronic osteomyelitis.

\begin{tabular}{ll}
\hline Classification type & Radiological appearance of the bone segment \\
\hline A & Abscess type, osteolytic area(s), no sequestrum, no involucrum \\
B1 & Peripheral, localised cortical sequestration, minimal/no involucrum \\
B2 & Sequestration present, stable, normal-looking, cortical involucrum \\
B3 & Sequestration present, stable, sclerotic involucrum \\
B4 & Sequestration present, unstable, inadequate involucrum \\
C & No sequestration visible on plain radiograph, densely, diffusely sclerotic bone segment; abscess may be present \\
Unclassified & Inadequate radiograph/disease onset $>$ six months/previous surgery \\
\hline
\end{tabular}

patients' socio-demographic characteristics. All continuous variables such as age and haematological parameters were reported as median and interquartile ranges because the data was not normally distributed after checking for normality of data using the Shapiro-Wilk test. To compare a continuous variable between cases and controls, a Mann-Whitney test was applied. Association between variables were determined using odds ratio and $95 \%$ confidence intervals (Cls) were also reported. Multivariate analysis was run by selecting those variables that appeared to have a p-value of $20 \%$ and below in the bivariate analysis. P-value of $<0.05$ was considered as statistical significance. Average marginal effects were run to assess the predictive probability of MM.

\section{Results}

In this study, the median age for cases was nine and half years ( 7 to 12 ) and these were significantly older than the controls whose median age was seven years ( 4 to 11 ) $(p=0.003)$. There were more females in the cases (33 $(57.9 \%))$ but more males in the controls $(60$ (52.6\%)). The majority of the participants in both cases (52 (91.2\%)) and controls (108 (94.7\%)) were follow-up patients. With regards to HIV, only four (7.0\%) cases and three $(2.6 \%)$ controls were tested positive (Table II).

Comparison of clinical and laboratory parameters. The median age at diagnosis of SCD was three years (1.2 to 4) for the cases and 1.1 (0.6 to 2.3) years for the controls $(p<0.001)$. The median annual frequency of VOCs in the cases was six (3 to 10) and in the controls was two (1 to $6)$ per year $(\mathrm{p}<0.001)$. The percentage of $\mathrm{HbS}$ was also higher in the cases compared to the controls ( $p<0.001)$, but the white blood cells were significantly lower in the cases compared to the controls $(p=0.006)$. Other parameters were not significantly different between the two groups (Table III).

Description of musculoskeletal manifestations in cases. The commonest $\mathrm{MM}$ was chronic osteomyelitis 17 (29.8\%), followed by acute osteomyelitis $12(21.1 \%)$, avascular necrosis of the femoral head eight (14.0\%), and septic arthritis six (10.5\%) (Figure 1). Other manifestations included: Leg ulcer, pathological fractures, vertebral collapse, and dactylitis. Of note is that all the children that presented with AVN of the femoral head were
Table II. Association of baseline demographic data.

\begin{tabular}{|c|c|c|c|}
\hline Variable & $\begin{array}{l}\text { Cases }(n= \\
57)\end{array}$ & $\begin{array}{l}\text { Controls }(n= \\
114)\end{array}$ & p-value * \\
\hline Age, yrs (range) & 9.5 (7 to 12$)$ & $7(4$ to 11$)$ & $0.003^{*}$ \\
\hline $\begin{array}{l}\text { Sex, } \mathbf{n}(\%) \\
\text { Female } \\
\text { Male }\end{array}$ & $\begin{array}{l}33(57.9) \\
24(42.1)\end{array}$ & $\begin{array}{l}54(47.4) \\
60(52.6)\end{array}$ & $0.195^{* *}$ \\
\hline $\begin{array}{l}\text { Patient category n (\%) } \\
\text { Inpatient } \\
\text { Outpatient }\end{array}$ & $\begin{array}{l}5(8.8) \\
52(91.2)\end{array}$ & $\begin{array}{l}6(5.3) \\
108(94.7)\end{array}$ & $0.382^{* * *}$ \\
\hline $\begin{array}{l}\text { Caregiver, n (\%) } \\
\text { Both parents } \\
\text { Mother only } \\
\text { Father only } \\
\text { Other }\end{array}$ & $\begin{array}{l}33(57.9) \\
17(29.8) \\
2(3.5) \\
5(8.8)\end{array}$ & $\begin{array}{l}84(73.7) \\
22(9.3) \\
0(0) \\
8(7.0)\end{array}$ & $0.062^{* * *}$ \\
\hline $\begin{array}{l}\text { Monthly income, } \mathbf{n}(\%) \\
<\$ 100 \\
\$ 101 \text { to } \$ 500 \\
\$ 501 \text { to } \$ 1,000 \\
>\$ 1,000\end{array}$ & $\begin{array}{l}24(42.1) \\
28(49.1) \\
5(8.8) \\
0(0)\end{array}$ & $\begin{array}{l}41(36.0) \\
47(41.2) \\
10(8.8) \\
16(14.0)\end{array}$ & $0.031^{* * *}$ \\
\hline $\begin{array}{l}\text { HIV status, n (\%) } \\
\text { Positive } \\
\text { Negative }\end{array}$ & $\begin{array}{l}4(7.0) \\
53(93.0)\end{array}$ & $\begin{array}{l}3(2.6) \\
111(97.4)\end{array}$ & $0.173^{* * *}$ \\
\hline
\end{tabular}

* Mann-Whitney test; ** Chi-square; *** Fisher's exact test

*Median and interquartile range reported

above the age of 11 years, while $83 \%$ of the children that presented with septic arthritis were below the age of five years (Table IV). The tibia $(n=12,41.4 \%)$, femur $(n=6$, $20.7 \%)$, humeri $(n=6,20.7 \%)$, and radii $(n=5,17.2 \%)$ were the commonest sites of MM. Using the Beit Cure classification to stage chronic osteomyelitis, we reported seven cases $(41.2 \%)$ of type $B_{3}$, six cases (35.3\%) of $B_{2}, 3$ cases $(17.6 \%)$ of $C$, and only one case $(5.9 \%)$ of $B_{1}$.

Predictors of musculoskeletal manifestations. In multivariable logistic regression analysis, increase in age, increase in the frequency of VOC (adjusted odds ratio $(A O R)=1.3$, $95 \% \mathrm{Cl} 1.09$ to $1.52 ; \mathrm{p}=0.009$ ) and increase in the percentage of $\mathrm{HbS}$ were found to be the main predictors of MM. For every year increase in age the odds ratio indicates that the likelihood of experiencing $\mathrm{MM}$ increased by a factor of nearly one and a half (AOR $=1.4,95 \% \mathrm{Cl}$ 1.04 to $1.55 ; p=0.043)$. For one unit increase in the frequency of VOC the odds ratio indicates that the likelihood of $\mathrm{MM}$ was increased by a factor of one and a third (AOR $=1.3,95 \% \mathrm{Cl} 1.09$ to $1.52 ; \mathrm{p}=0.009$ ). Similarly, for one 
Table III. Comparison of clinical and laboratory parameters between cases and controls.

\begin{tabular}{|c|c|c|c|}
\hline Variable & Cases $(n=57)$ & Controls $(n=147)$ & p-value \\
\hline $\begin{array}{l}\text { Age at SCD } \\
\text { diagnosis (years) }\end{array}$ & $3(1.2$ to 4$)$ & 1.1 (0.6 to 2.3 ) & $<0.001$ \\
\hline $\begin{array}{l}\text { Frequency of VOC } \\
\text { (per year) }\end{array}$ & $6(3$ to 10$)$ & 2 (1 to 6$)$ & $<0.001$ \\
\hline $\begin{array}{l}\text { Frequency of } \\
\text { blood transfusion }\end{array}$ & 1 (0 to 3$)$ & $1(0$ to 3$)$ & 0.766 \\
\hline $\begin{array}{l}\text { Type of } \\
\text { genotype }\end{array}$ & & & 0.31 \\
\hline Hbss & 56 & 112 & \\
\hline Other & 1 & 2 & \\
\hline $\begin{array}{l}\text { Percentage (\%) of } \\
\text { 'HbS' }\end{array}$ & 87.5 (85 to 90$)$ & 72.5 (63 to 82$)$ & $<0.001$ \\
\hline $\begin{array}{l}\text { Haemoglobin } \\
(\mathrm{g} / \mathrm{dL})\end{array}$ & $7(6.2$ to 7.6$)$ & $7.3(6.7$ to 8.1$)$ & 0.082 \\
\hline $\begin{array}{l}\text { White blood cell } \\
\text { count }\left(\times 10^{9} / \mathrm{L}\right)\end{array}$ & 12.5 (9.1 to 17.0$)$ & 14.4 (11.7 to 21.3$)$ & 0.006 \\
\hline $\begin{array}{l}\text { Neutrophil count } \\
\left(\times 10^{9} / \mathrm{L}\right)\end{array}$ & $5.2(4.0$ to 8.0$)$ & 6.5 (4.8 to 10.2 ) & 0.071 \\
\hline $\begin{array}{l}\text { Lymphocyte count } \\
\left(\times 10^{9} / \mathrm{L}\right)\end{array}$ & $4.4(3.4$ to 6.4$)$ & $5.3(3.8-7.2)$ & 0.053 \\
\hline $\begin{array}{l}\text { Alkaline } \\
\text { phosphatase (U/L) }\end{array}$ & 180.4 (142.8 to 227.0 ) & 180.2 (143.6 to 231.3 ) & 0.784 \\
\hline $\begin{array}{l}\text { Alanine } \\
\text { transaminase }(\mathrm{U} / \mathrm{L})\end{array}$ & 26.9 (18.2 to 32.1$)$ & 23 (17.0 to 28.8 ) & 0.221 \\
\hline $\begin{array}{l}\text { Aspartate } \\
\text { transaminase }(\mathrm{U} / \mathrm{L})\end{array}$ & 66 (54.1 to 83.3 ) & 58.9 (30.5 to 77.5$)$ & 0.051 \\
\hline $\begin{array}{l}\text { Direct bilirubin } \\
(\mu \mathrm{mol} / \mathrm{L})\end{array}$ & $16.2(9.1$ to 23.7$)$ & 11.2 (7.6 to 23$)$ & 0.269 \\
\hline $\begin{array}{l}\text { Total bilirubin } \\
(\mu \mathrm{mol} / \mathrm{L})\end{array}$ & 42.1 (12.6 to 61.1 ) & 33.5 (22.6 to 61.8$)$ & 0.723 \\
\hline $\begin{array}{l}\text { Lactate } \\
\text { dehydrogenase } \\
\text { (IU/L) }\end{array}$ & 749 (640.0 to 801.0$)$ & 822 (560.0 to 903.0$)$ & 0.255 \\
\hline
\end{tabular}

SCD, sickle cell disease; VOC, vaso-occlusive crisis.

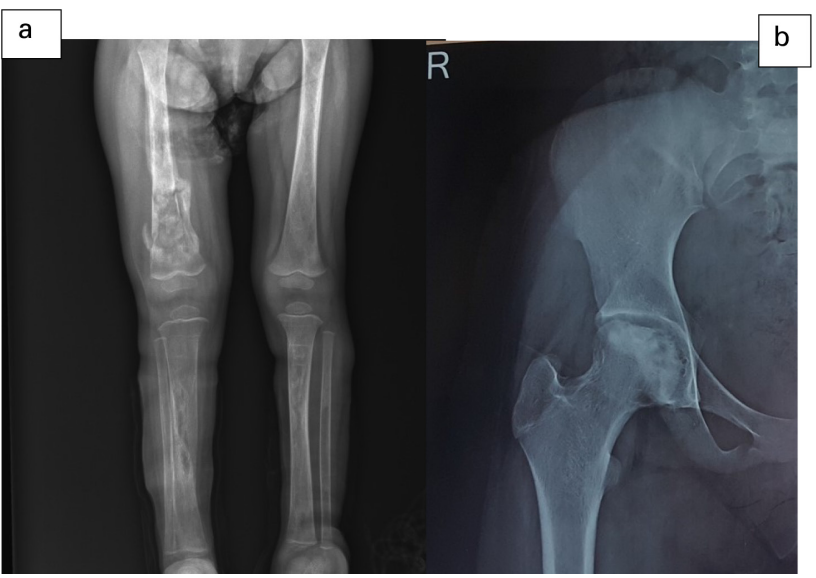

Fig. 1

Chronic osteomyelitis of right femur and bilateral tibia (a) and AVN of the right femoral head (b).

unit increase in the percentage of $\mathrm{HbS}$, the odds of experiencing $\mathrm{MM}$ were 1.18 higher than that of the controls (Table V).
Table IV. Types of musculoskeletal manifestations seen among cases.

\begin{tabular}{lll}
\hline Musculoskeletal manifestations & No of patients & Percentage \\
\hline Chronic osteomyelitis & 17 & 29.80 \\
Acute osteomyelitis & 12 & 21.05 \\
Avascular necrosis of femoral head & 8 & 14.04 \\
Septic arthritis & 6 & 10.53 \\
Leg ulcer & 5 & 8.77 \\
Pathological fracture & 3 & 5.26 \\
Vertebra collapse & 3 & 5.26 \\
Dactylitis & 3 & 5.26 \\
\hline
\end{tabular}

Table V. Adjusted logistic regression.

\begin{tabular}{lllc}
\hline Variable & AOR & $\mathbf{9 5 \%}$ CI & p-value * \\
\hline Age (yrs) & 1.20 & 1.04 to 1.45 & 0.043 \\
Age at diagnosis (yrs) & 1.12 & 0.83 to 1.29 & 0.435 \\
Frequency of VOC & 1.27 & 1.00 to 1.52 & 0.009 \\
Sex & & 0.81 to 4.71 & 0.675 \\
Male & Ref & & \\
Female & 1.36 & & \\
HIV status & & 0.63 to 4.92 & 0.913 \\
Negative & Ref & & \\
Positive & 1.04 & & \\
Percentage of HbS & 1.18 & 1.08 to 1.29 & $<.001$ \\
White cell count & 0.99 & 0.88 to 1.13 & 0.949 \\
Haemoglobin & 1.02 & 0.57 to 1.85 & 1.854 \\
Neutrophil count & 1.02 & 0.84 to 1.25 & 0.792 \\
Aspartate transaminase & 0.99 & 0.99 to 1.02 & 0.997 \\
\hline
\end{tabular}

$\mathrm{AOR}=$ Adjusted odds ratio; $\mathrm{Cl}=$ confidence interval; $\mathrm{VOC}=$ vaso-occlusive crisis; Ref.= reference category; $\mathrm{HbS}=$, Haemoglobin $\mathrm{S}$

Predictive margins of $\mathbf{M M}$. If there were two otherwiseaverage patients (keeping all other variables constant), one 16 years old and the other one two years old, for the 16-year-old the average probability of having MM would be 51 percentage points $(\mathrm{pp}=0.61,95 \% \mathrm{Cl}(0.43$, $0.80)$ higher than a two-year-old $(\mathrm{pp}=0.1,95 \% \mathrm{Cl}(0.0$ to 0.20$)$. For frequency of VOCs, on average if patient $A$ would experience twelve times per year $(p p=0.56,95 \%$ $\mathrm{Cl}(0.38$ to 0.64$)$ and patient $B$ twice per year $(p p=0.28$, $95 \% \mathrm{Cl}(0.18$ to 0.37$)$ the probability of patient A having MM would be 28 percentage points higher than patient $B$ (Figure 2).

\section{Discussion}

To the best of our knowledge, our study is the first to report predictors of $\mathrm{MM}$ in children with SCD in Zambia. In this study, the predictors of MM were increase in age of the participants, increase in age at diagnosis, increase in the percentage of $\mathrm{HbS}$, and frequency of VOC. Increase in age was a significant predictor of $\mathrm{MM}$ as well as increase in age at which SCD was diagnosed. A study in Nigeria by Chinawa et al, also noted in their study that the median age for patients with MM was found to be ten years and those without was nine years. ${ }^{9}$ Furthermore, manifestations such as AVN of the femoral head have a late presentation in the 

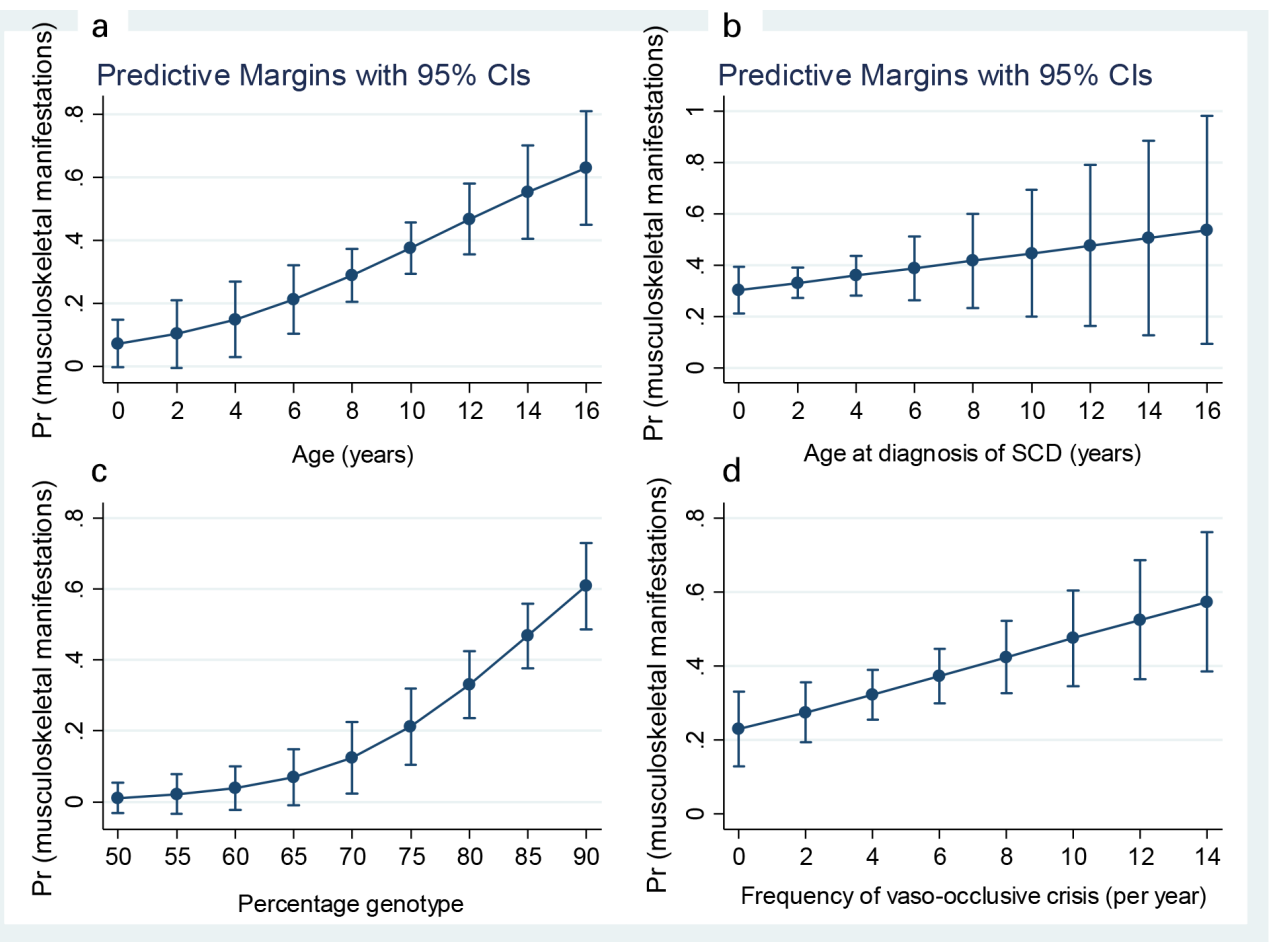

Fig. 2

Predictive margins for age (a), age at diagnosis of SCD (b); percentage of genotype (percentage of ' $\mathrm{Hb} \mathrm{s}$ ') (c), and frequency of VOC (d).

paediatric age group. Monagle et al ${ }^{16}$ postulated that worsening hypoxaemia, repeated infarction, and the development of the coagulation system as a child grows could be some of the reasons these $\mathrm{MM}$ are likely to present late.

VOC is the hallmark of SCD. ${ }^{7}$ In this study, the median annual frequency of VOC of the cases was six, while that of the controls was two. Frequency of VOC per year was a significant predictor MM. These findings are similar to the findings of the Mulago study in Uganda. ${ }^{11}$ The treatment protocol for our patients to prevent VOC is hydroxyurea and long-term blood transfusion protocol. This is supported by a review done by Yawn et al, who reported that the use of hydroxyurea and transfusion protocol is highly recommended for patients who have SCD to prevent VOC. ${ }^{17}$ However, Mahadeo et $\mathrm{al}^{18}$ reported that there was a $16.5 \%$ prevalence of $\mathrm{AVN}$ of the femoral head in SCD patients on hydroxyurea. It was noted in this study that, about $10 \%$ of patients who presented with AVN of the femoral head were on hydroxyurea. However, this study could not establish whether these patients had been commenced on hydroxyurea before or after the development of the AVN. The majority (98\%) of the patients had SCA i.e homozygous haemoglobin SS (HbSS) as their genotype and this was a significant predictor of MM. Hernigou et al ${ }^{19}$ found that of SCD patients who presented with septic arthritis, $94.9 \%$ of them had SCA. However, there was no significant association between the cases and the controls with regards to the genotype as only two patients (2\%) had a heterozygous genotype (HbSC and HbAS). Patients with SCA are the most affected in terms of severity of disease. ${ }^{20}$

Among the cases, the most common MM were chronic osteomyelitis (29.8\%), acute osteomyelitis (21.1\%), and AVN (14.1\%). Chinawa et al ${ }^{9}$ reported that the commonest MM they found was acute osteomyelitis at a study done at the University of Nigeria Teaching Hospital (UNTH) Ituku Ozalla in Nigeria. This difference could be attributed to the late referrals, delayed or missed diagnosis of the acute phase of the osteomyelitis especially for patients who are referred from rural settings. This could explain why there is an increased number of paediatric patients with SCD presenting with chronic osteomyelitis to the University Teaching Hospital, Lusaka. The Mulago study in Uganda revealed that the commonest $\mathrm{MM}$ was $\mathrm{AVN}$ of the femoral head. ${ }^{11}$ The difference here is that, in the Mulago study, the focus was on both paediatric and adult populations, whereas this study only focused on the paediatric population. Nevertheless, similar results were also noted in this study as all the children who presented with AVN of the femoral head were above the age of 11 years. As evident by these findings, it is clear to note that AVN of the femoral head, presents late in the paediatric patients with SCD.

The commonest site of osteomyelitis was the lower limbs, especially the Tibia (41.4\%). This is similar to findings in the Mulago study. ${ }^{11}$ In this study, the commonest stage of the chronic osteomyelitis was Beit 
Cure Classification type B3. It was also noted that the majority of cases were B-type (82.4\%). This is consistent with what Stevenson et al, found in the general population (88\%). ${ }^{14}$ Staphylococcus aureus was the commonest microorganism (66.7\%) cultured from the deep tissue samples taken during sequestrectomy. Our findings are in agreement with more recent studies that have reported Staphylococcus aureus to be the commonest causative organism in SCD patients. ${ }^{21-23}$ However, other previous authors found Salmonella to be the commonest causative organism. ${ }^{24,25}$ In this study, only six sequestrectomies out of the 17 patients who had chronic osteomyelitis were done during the study period. This could have affected the outcome. Of note is that only one $(16.7 \%)$ case of salmonella was cultured.

For other parameters such as haemoglobin concentration, white cell count, neutrophil count, and lymphocyte, there was no significant difference between cases and controls. This was in concordance with the report from the Mulago study except for the lymphocyte count which was significant in their study. ${ }^{11}$ In this study, the controls could have had other infective processes which could explain why there were no significant findings between the two groups. For the liver function test, only AST had a significant association $(p=0.01)$. These patients could also have had possible liver pathology as in SCD there is an association with chronic haemolysis. ${ }^{26}$

Our study had limitations. First, we cannot rule out information bias owing to misclassification and we relied on information given by the caregiver and from medical records both of which have possible errors. Second, although we aimed at collecting as many potential predictors as possible, there is a possibility of unmeasured cofounders which can happen in any observational study. Third, our study may not permit generalization to a wider population since it was conducted at a tertiary hospital located in the capital city, and predictors of MM in rural areas may be different.

In conclusion, we found that increase in age, increase in age at diagnosis, VOC and increase in the percentage of $\mathrm{HbS}$ were the predictors of musculoskeletal manifestations. The commonest MM were osteomyelitis (acute and chronic) and AVN of the femoral head. The findings have implications for establishing early screening programmes for the early diagnosis of the SCD to prevent the development of MM. Medical officers in referral centres should diagnose early or have a high index of suspicion for these MM in these patients, and may encourage earlier treatment.

\section{Twitter}

Follow R. M. Musowoya @RaymondMusowoya

Follow P. Kaonga @DrPatrickKaonga

Follow A. Bwanga @Ban2804

Follow C. Chunda-Lyoka @CLiyoka

Follow C. Lavy@chris_lavy

Follow J. Munthali @DrJamesMunthali

\section{References}

1. Bender MA. Sickle cell disease: University of Washington, Seattle; 2017. AccessedOctober 9, 2018. https://www.ncbi.nlm.nih.gov/sites/books/NBK1377/

2. Piel FB, Steinberg MH, Rees DC, Disease SC. Sickle cell disease. N Engl J Med. 2017;376(16):1561-1573.

3. Ejindu VC, Hine AL, Mashayekhi M, Shorvon PJ, Misra RR. Musculoskeletal manifestations of sickle cell disease. Radiographics. 2007;27(4):1005-1021.

4. Thein: World Sickle Cell Day 2016. A time for appraisal - Google Scholar. https:// scholar.google.com/scholar_lookup?hl=en\&volume=143\&publication_year=2016\& pages=678-681\&journal=Indian+J+Med+Res\&issue=6\&author=MS+Thein\&author= L+Swee\&title=Thein+World+Sickle+Cell+Day+2016\%3A+a+time+for+appraisal (date last accessed December 17, 2019).

5. Aygun B, Odame I. A global perspective on sickle cell disease. Pediatr Blood Cancer. 2012:59(2):386-390

6. Makani J, Ofori-Acquah SF, Nnodu O, Wonkam A, Ohene-Frempong K. Sickle cell disease: new opportunities and challenges in Africa. Scientific World Journal. 2013;2013:1.

7. Emmanuel C. Sickle cell anemia: practice essentials, background, genetics.. 2018. https://emedicine.medscape.com/article/205926-overview (date last accessed May 22, 2018).

8. Vaishya. Musculoskeletal Manifestations of Sickle Cell Disease: A Review. Published 2015.. https://www.ncbi.nlm.nih.gov/pmc/articles/PMC4659689/ (date last accessed May 22, 2018).

9. Chinawa. Musculoskeletal Complications Among Children with Sickle Cell Admitted in University of Nigeria Teaching Hospital Ituku - Ozalla Enugu: A 58 Month Review. Published 2013.. https://www.ncbi.nlm.nih.gov/pmc/articles/PMC3868124/ (date last accessed May 22, 2018).

10. Eyichukwu. Outcome of management of chronic osteomyelitis at National Orthopaedic Hospital, Enugu. - PubMed - NCBI. Published 2009.. https://www.ncbi. nlm.nih.gov/pubmed/19630329/ (date last accessed May 22, 2018).

11. Akaro IL, Madewo G, Orwotho N, et al. The prevalence and factors associated with musculoskeletal disorders, in patients with sickle cell anaemia, at Mulago national referral Hospital, Uganda. East Cent Afr J Surg. 2016;21(1):96-112.

12. Barclay GP, Jones HI, Splaine $\mathbf{M}$. A survey of the incidence of sickle cell trait and glucose-6-phosphate dehydrogenase deficiency in Zambia. Trans R Soc Trop Med Hyg. 1970;64(1):78-93.

13. Nchimba L. Prevalence of Hepatitis $B$ and $C$ in Sickle-Cell disease patients at University Teaching Hospital, Lusaka, Zambia. Published online February 23, 2015. http://dspace. unza.zm/xmlui/handle/123456789/3726 (date last accessed May 22, 2018).

14. Stevenson AJ, Jones HW, Chokotho LC, Beckles VLL, Harrison WJ. The Beit CURE Classification of Childhood Chronic Haematogenous Osteomyelitis--a guide to treatment. J Orthop Surg Res. 2015;10(1):144.

15. Jawad MU, Haleem AA, Scully SP. In brief: Ficat classification: avascular necrosis of the femoral head. Clin Orthop Relat Res. 2012;470(9):2636-2639.

16. Monagle $P$, Barnes $\mathbf{C}$, Ignjatovic V, et al. Developmental haemostasis. impact for clinical haemostasis laboratories. Thromb Haemost. 2006;95(2):362-372.

17. Yawn BP, Buchanan GR, Afenyi-Annan AN, et al. Management of sickle cell disease: summary of the 2014 evidence-based report by expert panel members. JAMA. 2014;312(10):1033-1048.

18. Mahadeo KM, Oyeku S, Moody K, et al. Hydroxyurea use is associated with avascular necrosis of the femoral head among children with sickle cell disease. Blood. 2008;112(11):2477-2477.

19. Hernigou P, Daltro G, Flouzat-Lachaniette C-H, Roussignol X, Poignard A Septic arthritis in adults with sickle cell disease often is associated with osteomyelitis or osteonecrosis. Clin Orthop Relat Res. 2010;468(6):1676-1681.

20. Ashley-Koch A, Yang 0, OIney RS, Hemoglobin S. Hb S) allele and sickle cel disease: a huge review. Am J Epidemiol. 2000;151(9):839-845

21. Nwadiaro HC, Ugwu BT, Legbo JN. Chronic osteomyelitis in patients with sickle cell disease. East Afr Med J. 2000;77(1):23-26.

22. Tekou H, Foly A, Akue B. [Current profile of hematogenous osteomyelitis in children at the Tokoin University Hospital Center in Lome, Togo. Report of 145 cases]. Med Trop. 2000;60(4):365-368.

23. Akakpo-Numado GK, Boume MA, Mihluedo-Agbolan KA, et al. Osteoarticula complications of sickle cell disease in children. Hard Tissue.. 2013;2(3).

24. Doppelt $\mathbf{E}$, de La Rocque $\mathbf{F}$, Morriet $\mathbf{Y}$, Reinert $\mathbf{P}$. [Osteomyelitis in patient with sickle cell disease]. Arch Fr Pediatr. 1990;47(10):715-720.

25. Onwubalili JK. Sickle cell disease and infection. J Infect. 1983;7(1):2-20.

26. Rees DC, Williams TN, Gladwin MT. Sickle-Cell disease. The Lancet 2010;376(9757):2018-2031 
Author information:

R. M. Musowoya, BSC HB, MBChB, MMed, FZCMS, Orthopaedic and Trauma Sur-

geon

A. Bwanga, BSc HB, MBChB, MCS (ECSA), MMed, FZCMS, General Surgeon Department of Surgery, University Teaching Hospital, Lusaka, Zambia.

- P. Kaonga, BSc, MPH, PhD, Immunologist and Biostatistician, Department of Epidemiology and Biostatistics, School of Public Health, University of Zambia, Lusaka, Zambia; Tropical Gastroenterology and Nutrition Group, School of Medicine, University of Zambia, Lusaka, Zambia.

- C. Chunda-Lyoka, BSc HB, MBChB, MSc, MMed, Consultant Paediatrician Paediatric Infectious Disease/Hematology/Oncology, Department of Paediatrics, University Teaching Hospital, Lusaka, Zambia.

- C. Lavy, OBE, MD, MCh, FCS, FRCS, Professor of Orthopaedics and Tropical Surgery, Consultant Orthopaedic Surgeon and Spine Surgeon, Nuffield Department of Orthopaedics, Rheumatology and Musculoskeletal Sciences, Oxford University, Oxford, UK

- J. Munthali, MBChB, MMed, FCS (ECSA), PgDIRE (UCT), Consultant Orthopaedic and Trauma Surgeon, Senior Lecturer, Department of Surgery, School of Medicine, University of Zambia, Lusaka, Zambia.
Author contributions:

R. M. Musowoya: Worked on conceptualization and methodology, Data collection, Validation, Wrote original draft.

P. Kaonga: Worked on study design, Data analysis, Methodology, Wrote manuscript and interpreted the result.

A. Bwanga: Participated on study design, Critically reviewed the study, Interpreted the result, Prepared the manuscript.

C. Chunda-lyoka: Participated on study design, Critically reviewed the study, Interpreted the result, Prepared the manuscript.

C. Lavy: Participated on study design, Critically reviewed the study, Interpreted the result, Prepared the manuscript.

J. Munthali: Participated on study design, Critically reviewed the study, Interpreted the result, Prepared the manuscript.

Ethical review statement:

Permission was obtained from the University Teaching Hospital management and approval for the study was obtained from ERES Converge IRB ref. no 2018-Oct-017.

(92020 Author(s) et al. This is an open-access article distributed under the terms of the Creative Commons Attribution Non-Commercial No Derivatives (CC BY-NC-ND 4.0) licence, which permits the copying and redistribution of the work only, and provided the original author and source are credited. See https://creativecommons.org/licenses/ by-nc-nd $/ 4.0 \%$. 